В.П. БАЗИК, Г.А. ТІХОСОВА, Л.А. ЧУРСІНА Херсонський національний технічний університет

\title{
ДОСЛІДЖЕННЯ ФІЗИКО-ХІМІЧНИХ ВЛАСТИВОСТЕЙ ПРИРОДНИХ НАПОВНЮВАЧІВ ДЛЯ ФЕНОЛ-ФОРМАЛЬДЕГІДНИХ КОМПОЗЦІЙНИХ МАТЕРІАЛІВ
}

\author{
В.П. БАЗИК, А.А. ТИХОСОВА, Л.А. ЧУРСИНА
} Херсонский национальный технический университет

\author{
ИССЛЕДОВАНИЕ ФИЗИКО-ХИМИЧЕСКИХ СВОЙСТВ \\ НАТУРАЛЬНЫХ НАПОЛНИТЕЛЕЙ ДЛЯ ФЕНОЛ- \\ ФОРМАЛЬДЕГИДНЫХ КОМПОЗИЦИОННЫХ МАТЕРИАЛОВ
}

\author{
V.P. BAZUK, H.A. TIKHOSOVA, L.A CHURSINA \\ Kherson national technical university
}

\section{RESEARCH OF PHYSICAL AND CHEMICAL PROPERTIES OF NATURAL FILLERS FOR PHENOL- FORMALDEHYDE COMPOSITION MATERIALS}

\section{https://doi.org/10.36910/6775-2310-5283-2018-11-07}

Мета. Визначення хімічного складу та змочуваності нових природних наповнювачів на основі волокон льону олійного й встановлення впливу хімічного складу наповнювачів на фізичні властивості фенол-формальдегідних композиційних матеріалів.

Методика. При дослідженні використовували передбачені діючими державними стандартами методи, які дозволять вивчити фізико-хімічні властивості природних наповнювачів з лубу льону олійного. Адгезійні властивості наповнювачів характеризуються показником змочування.

Результати. Встановлено, щзо луб після механічного оброблення після повного очищення від деревини не придатний для армування композиційних матеріалів через високу гідрофобність і низький вміст иелюлози, його змочуваність дорівнює 5,0-6,3 г, а вміст целюлози становить всього 49,73\%.

На основі аналізу анатомічної будови поперечних зрізів стебел соломи льону олійного встановлені причини низької змочуваності волокон лубу $i$ відсутності адгезї їх до полімерної матричі, які полягають у наявності на поверхні волокон кутинів високомолекулярних кислот $і$ жирів, стійких до дії сильних кислот і лугів, які надають волокнам лубу значної гідрофобності.

Експериментально підтверджено, щчо для одержання з лубу волокон льону олійного, придатних для армування композиційних матеріалів зі значенням змочуваності - 120 г $i$ $\longrightarrow 53$ 
вмістом иелюлози 95-98\%, необхідне хімічне оброблення лубу за спеціальними хімічним складом, режимами і параметрами варіння.

В результаті хімічного оброблення отримано волокно зі змочуваністю 104,9-122,8 г $i$ вмістом а-иелюлози 90,01-98,68 \%, яке пройшло апробацію на ООО «ТД ПластмасПрилуки», 3 нього отримані експериментальні зразки фенопластів, які повністю задовольняють вимоги ТУ У 25.2-32512498-001-2004 «Маса пресована фенольна».

Наукова новизна. Встановлено вплив хімічного складу та анатомічної будови наповнювачів на адгезійну здатність й фізичні властивості фенопластів.

Практична значимість. Одержані природні наповнювачі з волокон льону олійного можуть використовуватись для виготовлення композииійних матеріалів різного призначення. Встановлено вплив механічних $i$ фізичних технологічних операцій на можливість иілеспрямованого регулювання експлуатаційних властивостей фенопластів.

Ключові слова: наповнювачі, фенопласти, змочуваність, ударна в'язкість, гнучка напруга, хімічний склад.

\section{Постановка проблеми у загальному вигляді та ії зв'язок із важливим} науковими та практичними завданнями. Застосування волокон льону олійного як наповнювачів для виготовлення композиційних матеріалів можливе за умови відповідності фізико-механічних властивостей даної сировини вимогам технологій виробництва визначених композиційних матеріалів. Ці властивості лляної сировини повинні сформуватися за певних режимів та параметрів технологічного процесу іï первинної обробки при застосуванні інноваційних технологій комплексної переробки стебел соломи льону олійного.

\section{Аналіз останніх досліджень, у яких започатковано вирішення} проблеми. Останнім часом Європа та інші країни світу виявляють підвищений інтерес до використання льону олійного для виготовлення різних видів продукції технічного призначення в багатьох галузях промисловості. На основі світового досвіду використання соломи льону олійного можна зробити висновок, що вона є цінною сировиною для виготовлення товарів технічного призначення, які широко застосовуються в багатьох галузях промисловості.

Однак існує певний технологічний та маркетинговий бар'єр для промислового використання соломи льону олійного - відсутність відомостей про розробку та апробацію технологій одержання волокна 3 необхідними фізико-механічними показниками для виробництва технічного текстилю для армування композиційних матеріалів [1-3].

Цілі статті. Вивчення фізико-хімічних властивостей наповнювачів з лубу льону олійного, придатних для армування фенол-формальдегіних композиційних матеріалів. 
Об'єкт дослідження. Волокнисті наповнювачі з лубу льону олійного.

Методи дослідження. Адгезійні властивості наповнювачів характеризуються показником змочування, який оцінювали ваговим методом згідно 3 міждержавним стандартом ГОСТ 595-79 «Целлюлоза хлопковая», а експериментальні зразки фенопластів визначали за технічними умовами ТУ У 25.2-32512498-001-2004, затвердженими ДП «Чернігівстандартметрологія».

Виклад основного матеріалу дослідження 3 повним обгрунтуванням отриманих наукових результатів. Використання лубу та волокна льону олійного у виробництві композиційних матеріалів 3 впровадженням інноваційних технологій дозволить вітчизняним виробникам скласти конкуренцію закордонним в сегменті технічного текстилю, який найбільш швидко розвивається на даний час на світовому текстильному ринку. Однак, застосування льону олійного як сировини для одержання широкого асортименту композиційних матеріалів різного функціонального призначення можливе за умови відповідності його фізико-механічних властивостей вимогам технологій виробництва визначених виробів. Ці властивості лляної сировини повинні сформуватися за певних режимів i параметрів технологічного процесу іiї первинної обробки при застосуванні інноваційних технологій комплексної переробки стебел соломи льону олійного.

Для одержання наповнювачів у вигляді волокон із стебел соломи льону олійного, придатних для армування композиційних матеріалів, було розроблено алгоритм проведення наукових досліджень.

Згідно даного алгоритму на першому етапі в роботі здійснено вибір селекційних сортів льону олійного, які на даний час вирощуються в аграрному секторі України, здійснена оцінка технологічних характеристик стебел соломи.

На другому етапі з вибраних стебел соломи було отримано луб за відомою технологією обробки трести на куделеприготувальному агрегаті. Оброблення здійснювалось за оптимізованими режимами обробки стебел для одержання лубу з високим очищенням від костри.

На третьому етапі була проведена оцінка якості одержаного лубу, тобто встановлені його фізико-механічні характеристики.

На четвертому етапі проаналізовані фізико-хімічні характеристики лубу і встановлено рівень його придатності для армування композиційних матеріалів. За результатами аналізу якості лубу здійснено наукове обгрунтування необхідності підготовки волокна льону олійного для армування композиційних матеріалів. 
На п’ятому етапі проведена хімічна підготовка волокна шляхом варіння лубу в лужно-окислювальних розчинах для повного очищення лубу від інкрустів: лігніну, пектинових речовин, жировосків.

На шостому етапі визначалися фізико-хімічні характеристики волокна, отриманого після варіння лубу.

На сьомому етапі проведено порівняльний аналіз фізико-хімічних показників якості наповнювача-бавовни, який використовується в Україні, 3 такими ж показниками, одержаного в роботі наповнювача 3 волокна льону олійного. 3 одержаним в роботі волокном виготовлено експериментальні зразки композиційних матеріалів у виробничих умовах.

На восьмому етапі здійснено порівняльний аналіз фізико-механічних показників одержаних зразків композиційних матеріалів армованих бавовняним і лляним волокном та встановлена економічна доцільність заміни бавовни на волокна льону олійного в технологічному процесі формування композиційних матеріалів у умовах ДП «Пластмас» ТОВ «ТД ПластмасПрилуки».

Для визначення придатності лубу для виготовлення композиційних матеріалів нами були проведені дослідження в умовах підприємства ДП «Пластмас» ТОВ «ТД Пластмас-Прилуки» (м. Прилуки Чернігівської області). Для цього були виготовлені експериментальні зразки композиційних матеріалів, в яких в якості наповнювача використовували волокно льону олійного. Детально були досліджені фізико-механічні властивості волокна, отриманого 3 лубу, і проведено порівняльний аналіз фізико-механічних характеристик 3 бавовняним волокном, яке на сьогоднішній день використовується в якості наповнювача для виробництва композиційних матеріалів на вищезазначеному підприємстві.

За даними ДП «Пластмас» ТОВ «ТД Пластмас-Прилуки», відомо, що основним показником адгезії фенол-формальдегідних смол є змочуваність. Тому, спочатку використовували луб олійного льону без попередньої підготовки. Дослідження змочуваності лубу, наведені в роботі, показали, що луб льону олійного після механічної обробки майже не має змочуваності 5,06,3г. За стандартними вимогами волокно, яке застосовується як наповнювач для армування фенопластів, повинно мати змочуваність 110-120 г.

Щоб встановити причини такого низького значення змочувності лубу льону олійного було детально вивчено хімічний склад лубу та анатомічну будову стебел соломи льону олійного трьох сортів - Еврика, Лірина та Айсберг. 
Дослідження хімічного складу лубу після механічної підготовки, показали, що целюлоза складає у вибраних сортах лубу 47,67-53,33 \%, а інші супутники целюлози: лігнін - 16,66-22,31 \%, пектинові речовини - 15,24$20,65 \%$, воски - 18,13-18,5 \% (табл. 1).

Таблиця 1

Хімічний склад лубу льону олійного різних сортів після механічної обробки (до відварювання)

\begin{tabular}{|l|c|c|c|c|c|}
\hline \multirow{2}{*}{$\begin{array}{c}\text { Сорти льону } \\
\text { олійного }\end{array}$} & \multicolumn{5}{|c|}{ Хімічний склад } \\
\cline { 2 - 6 } & целюлоза & лігнін & $\begin{array}{c}\text { пектинові } \\
\text { речовини }\end{array}$ & $\begin{array}{c}\text { воскові } \\
\text { речовини }\end{array}$ & зола \\
\hline Еврика & 47,67 & 22,31 & 20,65 & 18,57 & 9,37 \\
\hline Лірина & 53,33 & 16,66 & 15,49 & 18,13 & 14,5 \\
\hline Айсберг & 48,20 & 21,96 & 15,24 & 18,32 & 14,6 \\
\hline $\begin{array}{l}\text { Середні } \\
\text { значення }\end{array}$ & 49,73 & 20,31 & 17,12 & 18,34 & 12,84 \\
\hline
\end{tabular}

Тобто, основний компонент целюлоза, який є у лубі льону олійного і відіграє вирішальну роль у формуванні композиційних матеріалів засмічений інкрустуючими компонентами, від яких необхідно вивільнити целюлозу.

Тому, другим важливим етапом підготовки лубу до використання його як наповнювача для формування композиційних матеріалів, окрім механічного оброблення стебел для звільнення від костриці, потрібна хімічна обробка лубу для очищення волокна від супутників целюлози та кутинів - восків високомолекулярних кислот та жирів.

На нашу думку, основною причиною низької змочуваності лубу є вміст на поверхні лляного волокна восків. При детальному вивченні анатомічної будови структури поперечного зрізу стебла соломи льону олійного встановлено, що ззовні стебло покрите кутикулою - 1, під нею знаходиться епідерміс - 2, за на ним - коркова паренхіма - 3, вона оточує волокнисті пучки - 4, з внутрішнього боку волокон знаходиться флоема - 5, ближче до центру знаходиться камбій - 6 і деревина - 7, 8 (ксилема і паренхіма), а по центру стебла розташована порожнина (рис. 1).

При повній зрілості стебел соломи льону олійного після їх механічної обробки з використанням процесу чесання, луб повністю звільняється від деревної частини: флоеми, ксилеми, паренхіми, а ззовні на волокнах залишається кутикула, що і надає волокнам гідрофобних властивостей. Кутикула являє собою цілісну безструктурну прозору плівку, яка в формі волосків заходить між волокнами. Кутикула складається 3 речовин, які називають кутинами - це високомолекулярні жирні кислоти, оксикислоти та жири. 


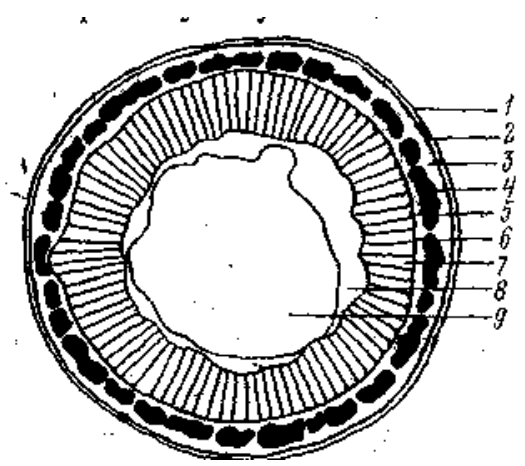

\section{Рис. 1. Анатомічна будова структури стебла соломи льону олійного}

Вони стійкі до дії сильних хімічних реагентів, таких як концентровані кислоти і луги, кутини нерозчинні в сірчаній, хромових кислотах і навіть у мідно-аміачному розчині, в якому розчиняється целюлоза.

При механічній обробці стебел соломи, що було здійснено на куделеприготувальному агрегаті і чесальних машинах, кутикула залишилася на волокні, про що свідчать поперечні зрізи волокон після механічної обробки.

Проведені теоретичні та експериментальні дослідження показали, що наявність кутинів на волокнах льону олійного надає їм таку велику гідрофобність, тому у них майже відсутня змочуваність - 5,0-6,3.

Тому, важливим етапом підготовки лубу до використання його як наповнювача для формування композиційних матеріалів, окрім механічного оброблення стебел для звільнення від костриці, потрібна хімічна обробка лубу для очищення волокна від супутників целюлози i кутинів високомолекулярних кислот та жирів.

Вивчивши всі відомі способи очищення лубу від супутників і восків науковцями Херсонського національного технічного університету було відібрано найбільш ефективний, 3 високим виходом целюлози окислювально-лужний спосіб. Саме за цим способом було здійснено відварку лубу льону олійного на лабораторному варочному апараті, одержаного після процесу чесання.

Весь технологічний процес відварки луб'яної та лубоволокнистої сировини був орієнтований на збереження целюлози, захист іiі від втрат i пошкодження та зменшення вмісту воскових речовин у волокні, які на нашу думку, заважають адгезії луб'яного волокна до фенол-формальдегідних смол. Тільки за умови зменшення воскових речовин у волокні може бути 
Товарознавчий вісник. - 2018. - Випуск 11.

забезпечено отримання високоякісних монолітних волокнистих композитівфенопластів.

У роботі були проведені дослідження зміни хімічного складу лубу та волокна, після процесу варіння з хімічними препаратами з метою звільнення від воскових речовин.

Отримані результати досліджень хімічного складу волокна трьох сортів льону олійного згідно з варіантами дослідів представлено в табл. 2.

Таблиця 2

Хімічний склад лубу льону олійного різних сортів після відварювання

\begin{tabular}{|l|c|c|c|c|}
\hline \multirow{2}{*}{$\begin{array}{c}\text { Сорти льону } \\
\text { олійного }\end{array}$} & \multicolumn{4}{|c|}{ Хімічний склад } \\
\cline { 2 - 5 } & 9 -целюлоза & лігнін & $\begin{array}{c}\text { пектинові } \\
\text { речовини }\end{array}$ & $\begin{array}{c}\text { воскові } \\
\text { речовини }\end{array}$ \\
\hline Еврика & 97,01 & 1,25 & залишки & 0,01 \\
\hline Лірина & 96,88 & 1,54 & - & 0,04 \\
\hline Айсберг & 94,785 & 1,30 & - & 0,02 \\
\hline $\begin{array}{l}\text { Середні } \\
\text { значення }\end{array}$ & 1,36 & & 0,03 \\
\hline
\end{tabular}

3 даних табл. 2 видно, що відварка лубу дозволила одержати волокно збагачене целюлозою, яке може бути використане як наповнювач для армування фенол-формальдегідних смол. Але однією важливою вимогою до целюлозовмісних наповнювачів $\epsilon$ їх висока змочуваність. Тому, паралельно 3 визначенням хімічного складу волокна була здійснена перевірка волокна після відварювання на такий важливий показник, як змочуваність. Результати цих досліджень наведені в табл. 3.

Таблиця 3

Фізико-хімічні показники якості волокна льону олійного різних сортів після хімічної обробки

\begin{tabular}{|l|c|c|c|}
\hline \multirow{2}{*}{ Сорт } & \multicolumn{3}{|c|}{ Показники якості } \\
\cline { 2 - 4 } & $\begin{array}{c}\text { масова частка } \alpha- \\
\text { целюлози, } \%\end{array}$ & змочуваність, г & Вихід целюлози, \% \\
\hline Айсберг & 96,88 & 104,94 & 11,5 \\
\hline Евріка & 97,68 & 105,39 & 12,2 \\
\hline Лірина & 90,01 & 122,80 & 11,8 \\
\hline
\end{tabular}

Дані табл. 3 свідчать про те, що після хімічної обробки лубу було одержано волокно, яке задовольняє вимоги, до наповнювачів, які висуваються ДП «Пластмас» ТОВ «ТД Пластмасс-Прилуки», змочуваність волокна підвищилась до необхідних показників 104,94-122,80 г. При подальших дослідженнях отримані зразки волокна пройшли виробничі випробування на ДП «Пластмас» ТОВ ТД «Пластмас-Прилуки». Для цього були виготовлені 
експериментальні зразки композиційних матеріалів, в яких у якості наповнювача використовували волокно льону олійного після хімічної підготовки.

Якість одержаних фенопластів, армованих лляним волокном, перевірялась відповідно до ТУ У 25.2-32512498-001-2004 «Маса пресувальна фенольна». Фізико-механічні показники якості фенопластів марки У1-301-07, армованих бавовняним волокном і волокном льону олійного, наведені в табл. 4.

Таблиця 4

\section{Порівняльний аналіз показників якості фенопластів, армованих} волокнами льону олійного і бавовни

\begin{tabular}{|c|c|c|c|c|c|}
\hline \multirow{3}{*}{ Показники якості } & \multicolumn{5}{|c|}{ Тип наповнювача } \\
\hline & \multirow{2}{*}{ показники } & \multicolumn{3}{|c|}{ лляні волокна сортів } & \multirow{2}{*}{ бавовна } \\
\hline & & Айсберг & Еврика & Лірина & \\
\hline Колір & $\begin{array}{c}\text { світло } \\
\text { коричневий до } \\
\text { темно } \\
\text { коричневого }\end{array}$ & відп. & відп. & відп. & відп. \\
\hline Зовнішній вигляд & $\begin{array}{c}\text { без тріщин i } \\
\text { раковин }\end{array}$ & відп. & відп. & відп. & відп. \\
\hline $\begin{array}{l}\text { Ударна в’язкість за } \\
\text { Шарлі на зразках без } \\
\text { надрізу кДж/м², не } \\
\text { менше }\end{array}$ & $8,8(9,0)$ & 10,4 & 11,2 & 9,0 & 12,4 \\
\hline 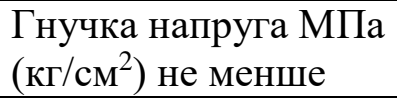 & 58,8 & 30,1 & 45,5 & 47,0 & 69,2 \\
\hline
\end{tabular}

Висновки та перспективи подальших досліджень. У результаті вивчення фізико-хімічних властивостей волокон льону олійного, одержаних після механічного оброблення та повного хімічного очищення від інкрустів, було встановлено, що дана сировина повністю відповідає вимогам до волокнистих наповнювачів фенопластів.

Лляне волокно 3 такими властивостями придатне для армування композиційних матеріалів різного функціонального призначення, що дає можливість розширення асортименту даних товарів.

\section{Література}

1. Чурсіна Л.А. Інноваційні технології одержання нетканих та целюлозовмісних матеріалів з льону олійного: [монографія] / Л.А. Чурсіна, Г.А. Тіхосова, Т.М. Головенко, I.О. Меняйло-Басиста. - Херсон: Грінь Д.С., 2014. - 304 с. 
2. Енеке Михаэль. Мировой рынок технического текстиля: влияние кризисна, тенденции, перспективы / Михаэль Енеке // Технический текстиль. - 2007. - № 29. - С. 8187.

3. Technische Textilen: Innovation, Technik, Anwendung. - May 2011, № 3. - S. 99.

Цель. Определение химического состава и смачиваемости новых природных наполнителей на основе волокон льна масличного и установление влияния химического состава наполнителей на физические свойства фенол-формальдегидных композиционных материалов.

Методика. При исследовании использовали предусмотренные действуюшими государственными стандартами методы, что позволит изучить физико-химические свойства природных наполнителей из луба льна масличного. Адгезионные свойства наполнителей характеризуются показателем смачивания.

Результаты. Установлено, что луб после механической обработки после полной очистки от древесины не пригоден для армирования композищионных материалов из-за высокой гидрофобности и низкого содержание иеллюлозы, его смачиваемость равна 5,06,32, а содержание целлюлозы составляет всего 49,73\%.

На основе анализа анатомического строения поперечных срезов стеблей соломы льна масличного установлены причины низкой смачиваемости волокон луба и отсутствия адгезии их к полимерной матрице, которые заключаются в наличии на поверхности волокон кутин - высокомолекулярных кислот и жиров, устойчивых к действию сильных кислот и щелочей, которые придают волокнам луба значительною гидрофобность.

Экспериментально подтверждено, что для получения из луба льна масличного, пригодных для армирования композиционных материалов со значением смачиваемости 1202 и содержанием иеллюлозы 95-98\%, необходима химическая обработка луба специальным химическим составом, по определенным режимам и параметрам варки.

В результате химической обработки получено волокно со смачиваемостью 104,9122,8г и содержанием $\alpha$-иеллюлозы 90,01-98,68\%, которое прошло апробацию на ООО «ТД Пластмасс-Прилуки», из него получены экспериментальные образиь фенопластов, которые полностью удовлетворяют требования ТУ У 25.2-32512498-001-2004 «Масса прессованная фенольная».

Научная новизна. Установлено влияние химического состава и анатомического строения наполнителей на адгезионную способность и физические свойства фенопластов.

Практическая значимость. Полученные природные наполнители из волокон льна масличного могут использоваться для изготовления композииионных материалов различного назначения. Установлено влияние механических и физических технологических операций на возможность иеленаправленного регулирования эксплуатационных свойств фенопластов.

Ключевые слова: наполнители, фенопласть, смачиваемость, ударная вязкость, гибкое напряжение, химический состав.

Aim. Determination of the chemical composition and wettability of new natural fillers on the basis of oil flax fibers and establishment of the influence of the chemical composition of fillers on the physical properties of phenol-formaldehyde composite materials.

Methods. The methods specified by the current state standards were used in the research, that will allow studying the physical and chemical properties of natural fillers from oil flax bast 
fiber. Adhesive properties of fillers are characterized by retting value.

Results. It was established that bast fiber after mechanical treatment and after complete wood refinement is not suitable for reinforcement of composite materials due to high hydrophobic property and low content of cellulose, its retting value is equal to 5.0-6.3 g, and the content of cellulose is only $49.73 \%$.

On the basis of the analysis of anatomical structure of transverse sections of stalks of oil flax straw, the reasons of low retting of bast fibers and their lack of adhesion to the polymer matrix, which are in the presence of cutins - high molecular acids and fats resistant to the action of strong acids and alkalis, which provide bast fibers with significant hydrophobicity, on the surface of the fibers have been determined.

It has been experimentally proved that for obtaining of oil flax fibers from bast fibers suitable for reinforcement of composite materials with retting value of $120 \mathrm{~g}$ and a content of cellulose 95-98\%, the chemical treatment of bast fiber is required by special chemical composition, modes and boiling parameters.

As a result of chemical treatment, a fiber with retting value of 104.9-122.8 $\mathrm{g}$ and $\mathrm{a}$ cellulose content of 90.01-98.68\% was obtained, which was tested in LLC "Trade House PlasticPryluky", and experimental samples of phenoplast were obtained from this fiber, which fully satisfy the requirements of TU U 25.2-32512498-001-2004 "Pressed Phenolic Mass."

Scientific novelty. The influence of chemical composition and anatomical structure of fillers on the adhesion ability and physical properties of phenoplast has been established.

Practical significance. The natural filler obtained from oil flax fibers can be used for making composite materials of various applications. The influence of mechanical and physical technological operations on the possibility of purposeful regulation of the operational properties of phenoplast has been established.

Key words: fillers, phenoplast, retting, impact strength, flexible tension, chemical composition.

Рекомендовано до публікації докт. техн. наук професором Кузьміною Т.О.

Стаття надійшла в редакиію 07.03.2018 р. 